\title{
SELEKSI DAN UJI POTENSI CENDAWAN DARK SEPTATE ENDOPHYTE SEBAGAI AGENSIA HAYATI PENYAKIT JAMUR AKAR PUTIH (Rigidoporus microporus) PADA TANAMAN KARET
}

\author{
Selection and Potential Test of Dark Septate Endophytes Fungus as Biological Agent \\ of White Root Rot Disease (Rigidoporus microporus) on the Rubber Plant \\ Cici Indriani DALIMUNTHE ${ }^{1,2 *}$, Bonny P W SOEKARNO ${ }^{2}$, \\ Abdul MUNIF ${ }^{2}$, dan SURONO ${ }^{3}$ \\ ${ }^{1}$ Balai Penelitian Sungei Putih, Pusat Penelitian Karet \\ Galang, Deli Serdang, PO BOX 1415 Medan 20001 Sumatera Utara \\ *E-mail: cc_dalimunthe@yahoo.com \\ ${ }^{2}$ Departemen Proteksi Tanaman, Institut Pertanian Bogor (IPB University) \\ Jalan Meranti Kampus IPB Dramaga Bogor 16680 Jawa Barat \\ ${ }^{3}$ Balai Penelitian Tanah \\ Jalan Tentara Pelajar Nomor 12 Cimanggu Bogor 16114 Jawa Barat
}

Diterima : 17 Mei 2019 / Disetujui : 13 Juni 2019

\begin{abstract}
Dark Septate Endophyte (DSE) fungus is a group of endophytic fungi that generally have dark melanin hyphae, form dark colonies on agar media, and are able to colonize plant roots without causing disease symptoms. No reports relating to the role of DSE fungi as biocontrol agents of white rot root disease, especially in Indonesia. This study aimed to obtain DSE fungal isolates from Indonesia by the selection of DSE fungal isolates that have the potency as biological agents of white root rot disease on the rubber plant. The initial stage of the study was the isolation of DSE fungi from roots and soil around rubber roots, pathogenicity test, dual culture test and metabolite test of volatile compounds. In this study, five DSE fungal isolates APDS 3.2, TBMDS 2.4b, TMDS 2.1, TMDS 3.2 and SBTBMDS 1 were able to inhibit the growth of Rigidoporus microporus causing white root rot disease on the rubber plant. This study proved that DSE fungal isolates can be isolated from rubber plant roots and have potential as a biological agent for Rigidoporus microporus causing white root rot disease on the rubber plant. Further studies will be carried out in the field testing and hoped the result of this study will provide preliminary information about the role of DSE fungus in rubber plants in overcoming biotic stress conditions caused by a pathogenic fungus.
\end{abstract}

Keywords: Biotic stress; DSE fungus volatile compound; dual culture; Hevea brasiliensis; Rigidoporus microporus

\begin{abstract}
Abstrak
Cendawan Dark Septate Endophyte (DSE) adalah sekelompok cendawan endofit yang memiliki hifa melanin gelap, membentuk koloni berwarna gelap pada media agar dan mampu mengkolonisasi akar tanaman tanpa menyebabkan gejala penyakit. Belum ada laporan yang berkaitan dengan peran cendawan DSE sebagai agens pengendali penyakit akar putih, khususnya di Indonesia. Penelitian ini bertujuan untuk mendapatkan isolat DSE dari Indonesia dengan cara menyeleksi isolat cendawan DSE yang berpotensi sebagai agensia hayati penyakit akar putih pada tanaman karet. Tahapan awal dari penelitian adalah isolasi cendawan DSE dari akar dan tanah di sekitar perakaran karet, uji patogensitas, uji dual culture dan uji metabolit senyawa volatil. Dalam penelitian ini, diperoleh lima isolat cendawan DSE APDS 3.2; TBMDS 2.4b; TMDS 2.1; TMDS 3.2 dan SBTBMDS 1 yang mampu menghambat pertumbuhan Rigidoporus microporus penyebab penyakit jamur akar putih pada tanaman karet. Penelitian ini membuktikan bahwa isolat cendawan DSE bisa diisolasi dari akar
\end{abstract}


tanaman karet dan berpotensi sebagai agensia hayati Rigidoporus microporus penyebab penyakit jamur akar putih pada tanaman karet. Penelitian selanjutnya akan dilakukan pengujian lapangan dan diharapkan hasil dari penelitian ini akan memberikan informasi awal tentang peran cendawan DSE pada tanaman karet dalam mengatasi cekaman biotik yang disebabkan oleh cendawan patogen.

Kata kunci: Cendawan DSE; dual culture; Hevea brasiliensis; Rigidoporus microporus; senyawa volatil; stres biotik

\section{PENDAHULUAN}

Pemanfaatan teknologi hayati berbahan aktif seperti cendawan dan bakteri telah menarik perhatian peneliti dan praktisi pertanian saat ini untuk mendukung pertanian yang ramah lingkungan dan berkelanjutan (Jia et al., 2016; Surono, 2017). Dalam praktik budidaya pertanian, tanaman juga mendapatkan keuntungan dari interaksi simbiosis dengan mikroorganisme seperti cendawan endofit. Beberapa penelitian sebelumnya melaporkan bahwa cendawan endofit berperan penting dalam meningkatkan pertumbuhan tanaman baik dalam kondisi nutrisi tercukupi untuk pertumbuhannya maupun dalam kondisi cekaman biotik karena serangan hama dan penyakit dan cekaman abiotik seperti keasaman yang tinggi dan kekeringan sehingga tanaman bisa beradaptasi dan tumbuh normal dalam kondisi cekaman tersebut (Surono \& Narisawa, 2017). Salah satu kelompok cendawan endofit yang telah dilaporkan dan berpotensi sebagai agensia hayati yang dapat memacu pertumbuhan tanaman pada kondisi cekaman baik abiotik dan biotik adalah kelompok cendawan Dark Septate Endophyte (DSE) (Santos et al., 2016; Liu et al., 2017; Surono, 2017; Surono \& Narisawa, 2018).

Cendawan DSE ini diharapkan dapat menjadi salah satu alternatif pengendalian penyakit jamur akar putih (JAP) yang disebabkan oleh Rigidoporus microporus. Penyakit JAP menyerang tanaman karet hampir di semua stadia pertumbuhan mulai dari pembibitan, tanaman belum menghasilkan (TBM) bahkan tanaman menghasilkan (TM) (Amaria et al., 2013). Kerugian finansial akibat kematian tanaman sekitar IDR 1,8 triliun (sekitar USD 200 juta) setiap tahunnya (Situmorang et al., 2007). Beberapa penelitian telah dilakukan untuk menguji keefektifan mikroba antagonis terhadap $R$. microporus (Jayasinghe, 2010). Di perkebunan karet, cendawan adalah agensia hayati yang telah lama dikenal dengan potensinya sebagai biofungisida (Jayasuriya \& Thennakoon, 2007). Banyak cendawan yang telah dijadikan sebagai biofungisida dan diproduksi secara komersial, salah satunya adalah Trichoderma spp. (Setyawan et al., 2013; Fairuzah et al., 2012). Cendawan endofit seperti Eupenicillium javanicum, Penicillium simplicissimum, $P$. citrinum, dan Hypocrea atroviridis juga berpotensi mengendalikan penyakit JAP (Amaria et al., 2013). Kaewchai dan Soytong (2010) juga melaporkan penggunaan biofungisida yang mengandung lima jenis cendawan, yaitu Aspergillus niger, Chaetomium bostrychodes, C. cupreum, T. hamatum, dan T. harzianum dapat menghambat perkembangan patogen R. microporus lebih dari 50\%.

Isolasi dan seleksi cendawan endofit dari lingkungan alam masih perlu dilakukan untuk mendapatkan spesies baru yang belum pernah dilaporkan sebelumnya (Rodriguez et al., 2009). Cendawan DSE dilaporkan bersimbiosis dengan 600 spesies tanaman seperti tanaman kehutanan dan pertanian (Jumpponen \& Trappe, 1998; Andrade-Linares et al., 2011; Mahmoud \& Narisawa, 2013). Hasil penelitian Surono dan Narisawa (2018) menunjukkan bahwa salah satu cendawan DSE, Phialocephala fortinii mampu menekan intensitas penyakit Fusarium pada tanaman asparagus. Penelitian dan publikasi terkait hubungan simbiosis antara cendawan DSE dengan tanaman karet di wilayah tropis khususnya di Indonesia belum ada yang melaporkan. Keunggulan cendawan DSE dibandingkan dengan agensia hayati lainnya adalah cendawan DSE ini dapat hidup pada dua kondisi cekaman baik faktor biotik maupun abiotik. Adanya pigmen melanin pada hifa DSE menjadikan cendawan ini mampu bertahan dan melindungi tanaman. Selain itu, DSE mampu mengkolonisasi akar tanaman baik secara interseluler maupun intraseluler tanpa menyebabkan penyakit (Surono, 2017). 
Penelitian ini bertujuan untuk seleksi dan uji potensi cendawan DSE sebagai agensia hayati penyakit jamur akar putih (JAP) pada tanaman karet. Dengan adanya informasi awal ini diharapkan nantinya akan dihasilkan teknologi formula agensia hayati multifungsi berbasis cendawan DSE yang dapat membantu meningkatkan pertumbuhan tanaman karet (biofertilizer) dan mengendalikan penyakit JAP pada tanaman karet (biofungisida).

\section{BAHAN DAN METODE}

Penelitian ini dilaksanakan di Laboratorium Biologi Tanah, Balai Penelitian Tanah, Cimanggu, Bogor dan Laboratorium Proteksi Balai Penelitian Sungei Putih, Galang, Deli Serdang pada bulan Juli 2018 sampai dengan Maret 2019. Lokasi pengambilan sampel akar dan tanah di sekitar perakaran karet dilakukan di Kebun Percobaan Balai Penelitian Sungei Putih, Galang, Deli Serdang pada berbagai umur tanaman karet meliputi pembibitan Tahun Tanam (TT) 2018, tanaman belum menghasilkan (TBM) TT 2014, dan tanaman menghasilkan (TM) TT 2006.

Tahapan-tahapan kegiatan penelitian meliputi sebagai berikut:

\section{Isolasi Cendawan DSE dari Akar dan Tanah Sekitar Perakaran Tanaman Karet}

Isolasi cendawan DSE dari akar mengikuti metode Surono dan Narisawa (2017) yang dimodifikasi. Sampel akar tanaman karet yang sehat dicuci dengan air mengalir, disterilisasi dengan $\mathrm{NaOCl} 1 \%$ sebanyak satu kali dan larutan tween 20 $(0,005 \%)$ sebanyak tiga kali. Dibilas tiga kali dengan air steril menggunakan vortex dan dikeringanginkan. Akar yang telah disterilisasi ditumbuhkan pada media 50\% corn meal agar (CMA) dan Potato Dextrose Agar (PDA) pada suhu $25^{\circ} \mathrm{C}$ dalam kondisi gelap. Koloni cendawan yang berwarna gelap yang tumbuh dari jaringan tanaman yang dipindahkan ke media PDA atau Oat Meal $\operatorname{Agar}(\mathrm{OMA})$.

Isolasi DSE dari tanah menggunakan teknik pengumpanan (soil baiting) mengikuti metode Narisawa (2008). Sampel tanah dicampurkan kompos dengan perbandingan $1 / 3(\mathrm{v} / \mathrm{v})$ hingga membentuk tanah komposit. Benih sawi putih (Chinese Cabbage) yang merupakan tanaman nonmikoriza digunakan untuk memicu kolonisasi DSE. Benih disterilisasi permukaan dan ditumbuhkan pada media tanam, setelah seminggu ditransplantasikan ke polybag berukuran $10,5 \mathrm{~cm}$ yang mengandung kira-kira 300 gr tanah komposit yang telah disiapkan sebelumnya. Tiga minggu setelah transplantasi, akar tanaman dikumpulkan dan dibersihkan dengan air mengalir dan dipilih 15 fragmen dari akar tanaman dan dari masing-masing fragmen dipotong kira-kira $1 \mathrm{~cm}$ per segmen. Setelah itu akar diisolasi untuk mendapat cendawan DSE yang berasal dari pengumpanan tanah (soil baiting).

\section{Uji Patogenisitas Cendawan DSE}

Uji patogenesitas cendawan DSE dilakukan dengan tujuan untuk melihat sifat patogenesitas cendawan DSE yang diperoleh apakah bersifat patogen atau non patogen. Benih yang digunakan adalah benih sawi putih (Chinese Cabbage) sebagai tanaman indikator (tanaman nonmikoriza) (Narisawa, 2008). Setiap benih disterilisasi permukaan dengan $70 \%$ ethanol selama 1,5 menit dan $1 \% \mathrm{NaOCl}$ selama 3 menit. Benih dibilas tiga kali dengan air steril lalu dikeringanginkan dan dilanjutkan dengan menanamkan benih pada media yang telah diinokulasikan DSE. Bibit yang ditanam pada media yang tidak diinokulasi DSE dijadikan sebagai kontrol. Setiap perlakuan dengan tiga ulangan termasuk kontrol. Parameter pengamatan meliputi persentase pertumbuhan, tinggi tanaman dan panjang akar. Isolat DSE yang tidak menimbulkan gejala penyakit akan digunakan pada pengujian selanjutnya.

\section{Uji Antagonis Cendawan DSE terhadap Rigidoporus microporus}

Pengujian dilakukan dengan metode biakan ganda (dual culture) mengikuti Amaria et al. (2013). Patogen R. microporus dan cendawan DSE diinokulasikan pada bagian tepi yang berbeda dan berjarak $3 \mathrm{~cm}$, kemudian diinkubasi pada suhu ruang. Pengamatan jari-jari koloni patogen $(\mathrm{cm})$ dilakukan pada pengamatan $2,4,6$, dan 8 hsi (hari setelah inokulasi) untuk mengetahui persentase penghambatan yang dihitung mengikuti Surono dan Narisawa (2018) menggunakan rumus: 
Penghambatan $(\%)=\frac{\mathrm{R} 1-\mathrm{R} 2}{\mathrm{R} 1} \times 100 \% \ldots \ldots . . \mathrm{i}$

di mana $R_{1}$ adalah jari-jari koloni patogen pada kontrol dan $\mathrm{R}_{2}$ adalah jari-jari koloni patogen menuju cendawan DSE. Isolat cendawan DSE yang memiliki daya hambat $\geq$ $50 \%$ yang akan digunakan sebagai bahan pengujian selanjutnya.

\section{Uji Senyawa Volatil Cendawan DSE Terpilih}

Uji senyawa volatil dilakukan dengan menggunakan dua cawan petri dengan ukuran diameter seragam (Raza et al. 2015). Isolat cendawan DSE dikulturkan pada media PDA kemudian ditutup dengan cawan petri yang telah dikulturkan dengan isolat cendawan $R$. microporus. Cawan petri direkatkan dengan menggunakan plastic wrap dan diinkubasi selama 7 hari pada suhu ruang. Persentase penghambatan dihitung menggunakan rumus:

$$
\mathrm{PI}=\frac{\phi \mathrm{K}-\phi \mathrm{P}}{\phi \mathrm{K}} \times 100 \%
$$

Keterangan (remarks): PI = Persentase penghambatan $(\%), \phi \mathrm{K}=$ diameter $R$. microporus pada perlakuan kontrol, $\phi \mathrm{P}=$ diameter $R$. microporus pada perlakuan cendawan DSE.

\section{Analisis Data}

Data yang diperoleh dari setiap pengujian dianalisis menggunakan ANOVA dan selanjutnya diuji dengan Uji Tukey pada taraf 5\%. Analisis dilakukan dengan menggunakan perangkat lunak SAS 9.4.

\section{HASIL DAN PEMBAHASAN}

\section{Seleksi cendawan DSE dari jaringan akar dan tanah sekitar perakaran tanaman karet}

Hasil isolasi cendawan DSE dari jaringan akar dan tanah sekitar perakaran tanaman karet diperoleh 25 isolat cendawan DSE. Sebanyak 23 isolat diperoleh secara langsung dari jaringan akar pembibitan, tanaman belum menghasilkan dan tanaman menghasilkan (TM) karet, dan 2 isolat cendawan DSE diperoleh secara tidak langsung dari teknik pengumpanan tanah (soil baiting) yang diambil dari tanah sekitar perakaran tanaman karet. Hasil isolasi cendawan DSE lebih banyak diperoleh dari isolasi pada akar tanaman pembibitan sebanyak 11 isolat DSE, tanaman belum menghasilkan (TBM) sebanyak 9 isolat, tanaman menghasilkan (TM) sebanyak 3 isolat, dan teknik soil baiting diperoleh sebanyak 2 isolat (Tabel 1). Banyak faktor yang mempengaruhi keragaman hayati cendawan DSE pada tanaman karet, salah satunya fase umur tanaman yang secara tidak langsung mempengaruhi pola terbentuknya akar tanaman yang bisa bersimbiosis dengan cendawan DSE (Sondergaard et al., 2004). Selain itu, faktorfaktor lingkungan seperti kondisi kesuburan tanah, tipe vegetasi, kondisi geografis lokasi juga mempengaruhi keragaman cendawan DSE yang bersimbiosis dengan tanaman

Table 1. Jumlah cendawan Dark Septate Endophyte (DSE) yang diperoleh dari akar dan tanah sekitar perakaran tanaman karet

Table 1. The number of Dark Septate Endophytic fungal isolates obtained from roots and soil around rubber plant

\begin{tabular}{lccc}
\hline \multicolumn{1}{c}{$\begin{array}{c}\text { Asal cendawan DSE } \\
\text { Source of DSE fungal }\end{array}$} & $\begin{array}{c}\text { Patogen } \\
\text { Pathogen }\end{array}$ & $\begin{array}{c}\text { Non-Patogen } \\
\text { Non-Pathogen }\end{array}$ & $\begin{array}{c}\text { Total } \\
\text { Total }\end{array}$ \\
\hline $\begin{array}{l}\text { Akar pembibitan karet } \\
\text { (berumur < 1 tahun ) }\end{array}$ & 3 & 8 & 11 \\
$\begin{array}{l}\text { Akar tanaman karet belum } \\
\text { menghasilkan (berumur } \pm 3 \text { tahun) }\end{array}$ & 6 & 3 & 9 \\
$\begin{array}{l}\text { Akar tanaman karet menghasilkan } \\
\text { (berumur }>5 \text { tahun) }\end{array}$ & 1 & 2 & 3 \\
$\begin{array}{l}\text { Soil Baiting menggunakan tanaman } \\
\text { nonmikoriza }\end{array}$ & 0 & 2 & 2 \\
\hline \multicolumn{1}{c}{ Total } & 10 & 15 & 25 \\
\hline
\end{tabular}


tanaman inang tertentu (Sieber \& Grunig, 2006).

Seleksi awal isolat cendawan DSE dilakukan dengan uji patogenisitas pada tanaman Chinese cabbage sebagai tanaman indikator. Benih yang tidak dapat berkecambah atau benih dapat berkecambah tetapi pertumbuhannya tidak normal merupakan indikator bahwa cendawan tersebut bersifat patogenik atau potensial patogenik (Irawati, 2017). Sedangkan cendawan yang bersifat nonpatogenik menunjukkan benih dapat berkecambah dan tumbuh normal (Gambar $1)$.
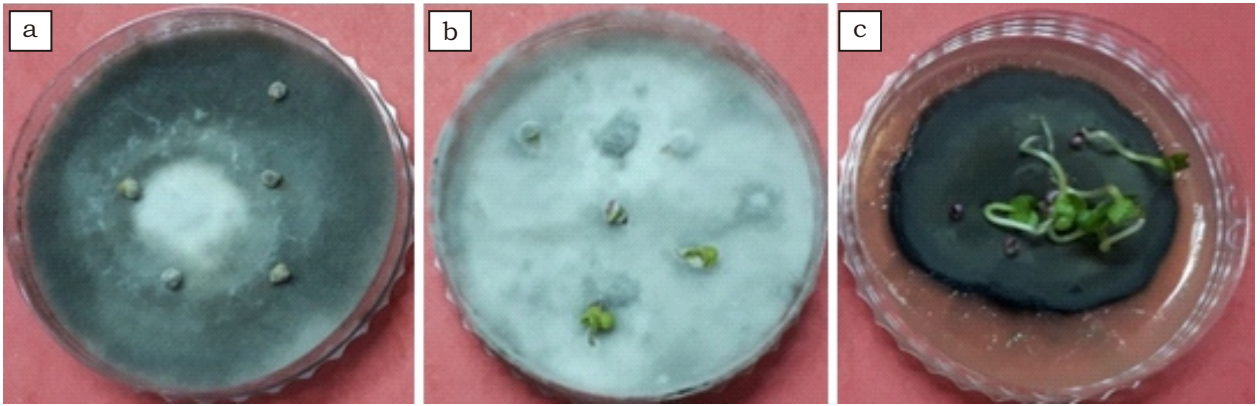

Gambar 1. Hasil uji patogenesitas cendawan DSE: cendawan patogenik (a), cendawan potensi patogenik (b), dan cendawan non-patogenik (c)

Figure 1. The result of pathogenicity test DSE fungus: pathogenic fungus (a), potential pathogenic fungus (b), and non-pathogenic fungus (c)

Hasil uji patogenesitas 25 isolat cendawan DSE pada tanaman Chinese Cabbage menunjukkan bahwa 15 isolat tidak bersifat patogen pada tanaman tersebut, sedangkan sisanya patogenik (Tabel 2). Isolat cendawan DSE yang memiliki persentase perkecambahan benih sebesar $100 \%$ dan tumbuh normal sebanyak 11 isolat antara lain APDS 3.2, APDS 2.1, APDS 2.3, APDS 2.4a, APDS 1.3, TBMDS 1.3, TBMDS 2.4b, TMDS 3.2, TMDS 2.1, SBTBMDS 1, dan SBTBMDS 2. Hasil seleksi awal ini dijadikan indikator untuk pengujian selanjutnya.

\section{Hasil Uji Antagonis Cendawan DSE terhadap Rigidoporus microporus}

Isolat cendawan DSE yang diuji dual culture antara lain APDS 3.2, APDS 2.1, APDS 2.3, APDS 2.4a, APDS 1.3, TBMDS 1.3, TBMDS 2.4b, TMDS 3.2, TMDS 2.1, SBTBMDS 1, dan SBTBMDS 2. Isolat cendawan DSE tersebut telah terseleksi dari hasil uji patogenesitas dan merupakan isolat cendawan non-patogenik. Hasil pengamatan 2 hari setelah inokulasi (hsi) menunjukkan bahwa cendawan DSE menghambat perkembangan cendawan patogen < 10\% dan ini tidak berbeda nyata antar perlakuan. Pada pengamatan 4 dan 6 hsi menunjukkan bahwa tiga isolat cendawan DSE yang mampu menghambat perkembangan patogen $R$. microporus $>50 \%$ yakni APDS 3.2, TBMDS 2.4b, dan TMDS 3.2. Sedangkan pada pengamatan 8 hsi menunjukkan bahwa ada lima isolat cendawan DSE yang mampu menghambat perkembangan patogen $R$. microporus $>50 \%$ yakni APDS 3.2, TBMDS 2.4b, TMDS 2.1, TMDS 3.2, dan SBTBMDS 1 (Tabel 3).

Persentase penghambatan tertinggi terdapat pada isolat APDS 3.2 sebesar 93,58\%, tidak berbeda nyata dengan TBMDS 2.4 b sebesar $91,92 \%$ (Gambar 1). Persentase penghambatan tertinggi ketiga adalah TMDS 3.2 sebesar $70,92 \%$. Isolat cendawan DSE APDS 3.2 dan TBMDS 2.4b memiliki daya hambat tinggi dan merupakan isolat yang pertumbuhan koloninya lebih cepat dibandingkan koloni patogen $R$. microporus dan tampak perkembangan koloni cendawan DSE menyelimuti dan menekan perkembangan koloni patogen $R$. microporus (Gambar 2). Berbeda halnya dengan isolat cendawan DSE TMDS 2.1, TMDS 3.2, dan SBTBMDS 1 terlihat antara patogen dan DSE masih saling bertahan. Isolat cendawan DSE yang diuji tersebut memiliki lebih dari satu mekanisme antagonis dalam menghambat pertumbuhan patogen meliputi kompetisi ruang dan nutrisi, memproduksi senyawa allelokimia yang 
Tabel 2. Persentase perkecambahan (\%) dan hasil patogenesitas dari cendawan Dark Septate Endophyte menggunakan tanaman 'nonmikoriza' Chinese cabbage

Table 2. Seed germination rate (\%) dan the result of pathogenicity test of Dark Septate Endophytic fungal isolates using 'non-mycorrhizal' plants Chinese cabbage seed.

\begin{tabular}{|c|c|c|c|}
\hline $\begin{array}{l}\text { No } \\
\text { No }\end{array}$ & $\begin{array}{l}\text { Kode isolat } \\
\text { Isolate code }\end{array}$ & $\begin{array}{c}\text { Persentase Perkecambahan } \\
\text { Seed germination rate } \\
(\%)\end{array}$ & $\begin{array}{l}\text { Hasil patogenesitas } \\
\text { Result of pathogenicity }\end{array}$ \\
\hline $\begin{array}{l}1 \\
2 \\
3 \\
4 \\
5 \\
6 \\
7 \\
8 \\
9 \\
10 \\
11 \\
12 \\
13 \\
14 \\
15 \\
16 \\
17 \\
18 \\
19 \\
20 \\
21 \\
22 \\
23 \\
24 \\
25 \\
26\end{array}$ & $\begin{array}{l}\text { APDS 3.2 } \\
\text { APDS } 2.1 \\
\text { APDS } 2.3 \\
\text { APDS } 2.4 \mathrm{a} \\
\text { APDS } 1.3 \\
\text { TBMDS } 1.3 \\
\text { TBMDS } 2.4 \mathrm{~b} \\
\text { TMDS } 3.2 \\
\text { TMDS } 2.1 \\
\text { SBTBMDS } 1 \\
\text { SBTBMDS } 2 \\
\text { Kontrol } \\
\text { APDS } 1.2 \\
\text { KBTU } 14 \\
\text { APDS } 1.1 \mathrm{a} \\
\text { TBMTS } 4 \\
\text { APDS } 1.1 \mathrm{~b} \\
\text { APDS } 2.2 \\
\text { APDS } 3.3 \\
\text { TBMDS } 1.4 \\
\text { TBMDS } 2.1 \\
\text { TBMTS } 2.1 \\
\text { TBMTS } 5 \\
\text { TBMTS } 6 \\
\text { TBMTS } 7 \\
\text { TMDS } 1.1\end{array}$ & $\begin{array}{l}100,00 a \\
100,00 a \\
100,00 a \\
100,00 a \\
100,00 a \\
100,00 a \\
100,00 a \\
100,00 a \\
100,00 a \\
100,00 a \\
100,00 a \\
100,00 a \\
77,78 \mathrm{a} \\
77,78 \mathrm{a} \\
66,67 \mathrm{a} \\
55,56 \mathrm{a} \\
44,44 \mathrm{a} \\
0,00 \mathrm{~b} \\
0,00 \mathrm{~b} \\
0,00 \mathrm{~b} \\
0,00 \mathrm{~b} \\
0,00 \mathrm{~b} \\
0,00 \mathrm{~b} \\
0,00 \mathrm{~b} \\
0,00 \mathrm{~b} \\
0,00 \mathrm{~b}\end{array}$ & $\begin{array}{l}\text { Non-Patogen } \\
\text { Non-Patogen } \\
\text { Non-Patogen } \\
\text { Non-Patogen } \\
\text { Non-Patogen } \\
\text { Non-Patogen } \\
\text { Non-Patogen } \\
\text { Non-Patogen } \\
\text { Non-Patogen } \\
\text { Non-Patogen } \\
\text { Non-Patogen } \\
\text { Non-Patogen } \\
\text { Non-Patogen } \\
\text { Non-Patogen } \\
\text { Non-Patogen } \\
\text { Non-Patogen } \\
\text { Patogen } \\
\text { Patogen } \\
\text { Patogen } \\
\text { Patogen } \\
\text { Patogen } \\
\text { Patogen } \\
\text { Patogen } \\
\text { Patogen } \\
\text { Patogen } \\
\text { Patogen }\end{array}$ \\
\hline
\end{tabular}

Angka-angka yang diikuti oleh huruf yang berbeda pada kolom yang sama berbeda nyata pada Uji Tukey pada taraf $5 \%$

Number followed by the different letter on same column were significantly different based on Tukey Test at $5 \%$ significant level

Tabel 3. Persentase penghambatan isolat cendawan Dark Septate Endophyte terhadap pertumbuhan Rigidoporus microporus pada pengamatan 2, 4, 6, dan 8 hari setelah inokulasi (hsi)

Table 3. Percentage of inhibition of Dark Septate Endophytic fungal isolates to Rigidoporus microporus growth at 2,4,6, and 8 day afterinoculation (dai).

\begin{tabular}{lllll}
\hline \multirow{2}{*}{$\begin{array}{c}\text { Perlakuan } \\
\text { Treatments }\end{array}$} & \multicolumn{4}{c}{ Pengamatan ke- } \\
\cline { 2 - 5 } & $2 \mathrm{HSI}$ & $4 \mathrm{HSI}$ & $6 \mathrm{HSI}$ & $8 \mathrm{HSI}$ \\
& $2 \mathrm{DAI}$ & $4 \mathrm{DAI}$ & $6 \mathrm{DAI}$ & $8 \mathrm{DAI}$ \\
\hline APDS 3.2 & $7,29 \mathrm{a}$ & $52,13 \mathrm{ab}$ & $77,17 \mathrm{a}$ & $93,58 \mathrm{a}$ \\
APDS 2.1 & $7,29 \mathrm{a}$ & $16,77 \mathrm{bcd}$ & $16,34 \mathrm{~cd}$ & $49,21 \mathrm{~cd}$ \\
APDS 2.3 & $2,08 \mathrm{a}$ & $7,82 \mathrm{~d}$ & $6,29 \mathrm{~d}$ & $22,83 \mathrm{e}$ \\
APDS 2.4a & $7,29 \mathrm{a}$ & $21,59 \mathrm{bcd}$ & $41,31 \mathrm{bc}$ & $39,42 \mathrm{de}$ \\
APDS 1.3 & $7,29 \mathrm{a}$ & $28,15 \mathrm{bcd}$ & $46,40 \mathrm{~b}$ & $49,00 \mathrm{~cd}$ \\
TBMDS 1.3 & $7,29 \mathrm{a}$ & $45,02 \mathrm{abc}$ & $39,84 \mathrm{bc}$ & $45,38 \mathrm{~cd}$ \\
TBMDS 2.4b & $7,29 \mathrm{a}$ & $72,93 \mathrm{a}$ & $83,28 \mathrm{a}$ & $91,92 \mathrm{a}$ \\
TMDS 2.1 & $7,29 \mathrm{a}$ & 16,49 & $41,46 \mathrm{bc}$ & $54,71 \mathrm{bcd}$ \\
TMDS 3.2 & $7,29 \mathrm{a}$ & $67,84 \mathrm{a}$ & $51,20 \mathrm{~b}$ & $70,92 \mathrm{~b}$ \\
SBTBMDS 1 & $7,29 \mathrm{a}$ & $22,23 \mathrm{bcd}$ & $42,46 \mathrm{~b}$ & $60,46 \mathrm{bc}$ \\
SBTBMDS 2 & $7,29 \mathrm{a}$ & $12,67 \mathrm{~cd}$ & $28,33 \mathrm{bcd}$ & $36,08 \mathrm{de}$ \\
\hline
\end{tabular}

Angka-angka yang diikuti oleh huruf yang berbeda pada kolom yang sama berbeda nyata pada Uji Tukey pada taraf $5 \%$

Number followed by the different letter on same column were significantly different based on Tukey Test at $5 \%$ significant level 

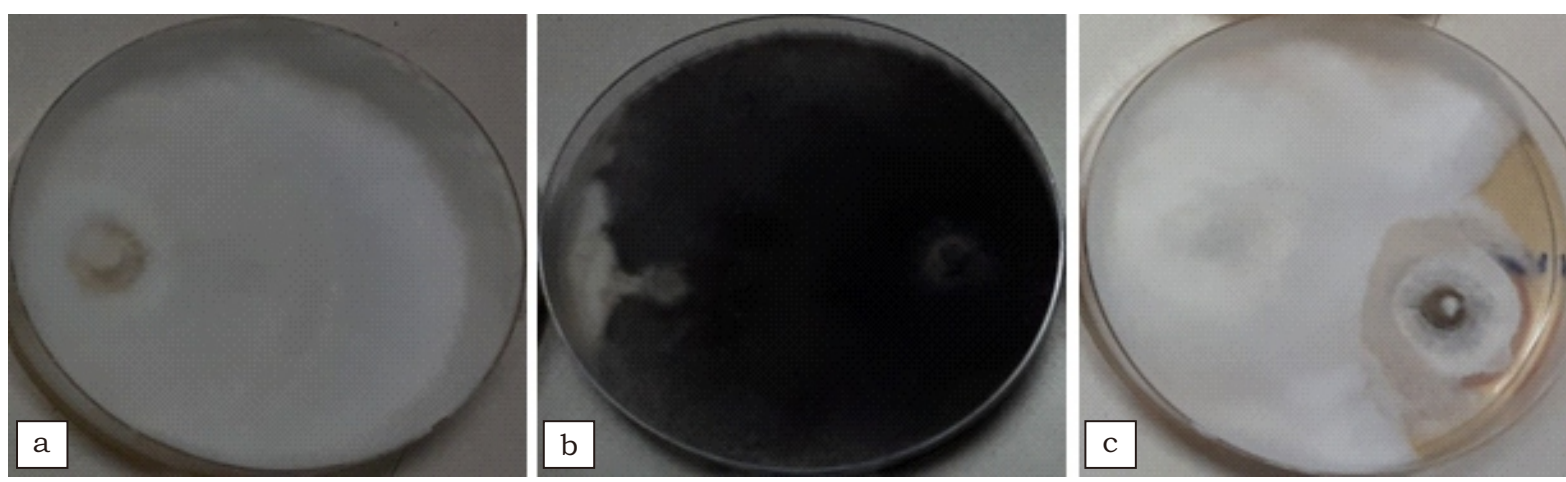

Gambar 2. Hasil antagonis isolat cendawan DSE, kontrol (tanpa DSE) (a); isolat APDS 3.2, cendawan DSE tampak menutupi sebagian kecil koloni $R$. microporus, dengan koloni patogen masih terlihat (b) dan isolat SBTBMDS1, cendawan DSE, dan JAP saling bertahan satu sama lain (c)

Figure 2. Antagonistic test of DSE fungus isolates; control (without DSE) (a); APDS 3.2 isolate, $D S E$ like covering a small portion of $R$. microporus colony, with the pathogen colony was still visible (b) and SBTMBDS1 isolate, it appears that pathogens, and DSE still survive each other (c)

bersifat menghambat patogen dan menginduksi ketahanan sistemik (ISR) tanaman inang (Compant et al. 2005). Hal ini sesuai dengan Agrios (2005) yang menyatakan bahwa mekanisme biokontrol adalah melemahkan atau membunuh patogen tanaman dengan perlawanan yaitu memparasit patogen secara langsung, memproduksi antibiotik (toksin), dan kemampuannya dalam kompetisi ruang dan nutrisi.

Pada umumnya cendawan genus Trichoderma yang telah banyak diteliti yang memiliki hubungan simbiosis dengan tanaman karet. Beberapa hasil penelitian terkait hal tersebut antara lain cendawan Trichoderma harzianum sebagai salah satu agens bio kontrol terhadap $R$. microporus (Jayasuriya \& Thennakoon, 2007). Selain itu juga, cendawan $T$. koningii dan $T$. viridae telah diformulasikan dalam suatu biofungisida di Indonesia (Fairuzah et al., 2012; Setyawan et al., 2013). Hasil penelitian ini menunjukkan bahwa Cendawan DSE memiliki potensi sebagai agensia hayati Rigidoporus microporus penyebab penyakit jamur akar putih pada tanaman karet. Cendawan DSE APDS 3.2 dan TBMDS 2.4b memiliki kemampuan berkompetisi dengan patogen terutama sebagai mikoparasit dan memiliki pertumbuhan yang cepat yaitu dalam waktu tiga hari telah menutupi cawan petri sama halnya seperti Trichoderma sp.

\section{Pengaruh Senyawa Volatil Organik Cendawan DSE Terpilih terhadap Pertumbuhan Rigidoporus microporus}

Hasil pengujian dual culture diperoleh 5 isolat DSE yang memiliki persentase penghambatan di atas > 50\% yaitu isolat APDS 3.2, TBMDS 2.4b, TMDS 2.1, TMDS 3.2, dan SBTBMDS1. Selanjutnya dilakukan uji produksi senyawa volatil cendawan DSE terpilih. Selain bersifat antibiosis, cendawan DSE yang diisolasi juga dapat menghasilkan volatile organic compound (VOC). VOC merupakan molekul rendah karbon yang dapat menguap dengan mudah pada suhu dan tekanan normal dan fungsinya sebagai antimikroba (Wheatley, $2002)$. Cendawan endofit dapat mengeluarkan senyawa antibiotik atau alkaloid yang mudah menguap (Siri-udom et al., 2015). Hasil pengamatan menunjukkan senyawa volatil yang dihasilkan oleh isolat cendawan DSE TBMDS 2.4b, dan APDS 3.2 mampu menghambat perkembangan $R$. microporus $>50 \%$ pada pengamatan ke 4,6 , dan 8 hari setelah inokulasi (hsi) (Gambar 3). Sedangkan isolat lainnya seperti TMDS 2.1, TMDS 3.2, dan SBTBMDS 1 tidak mampu menghambat perkembangan $R$. microporus dari senyawa volatil yang dihasilkan isolat tersebut. Menurut Wheatley (2002) bentuk interaksi VOC dapat bersifat positif, negatif, atau interaksi yang netral. 


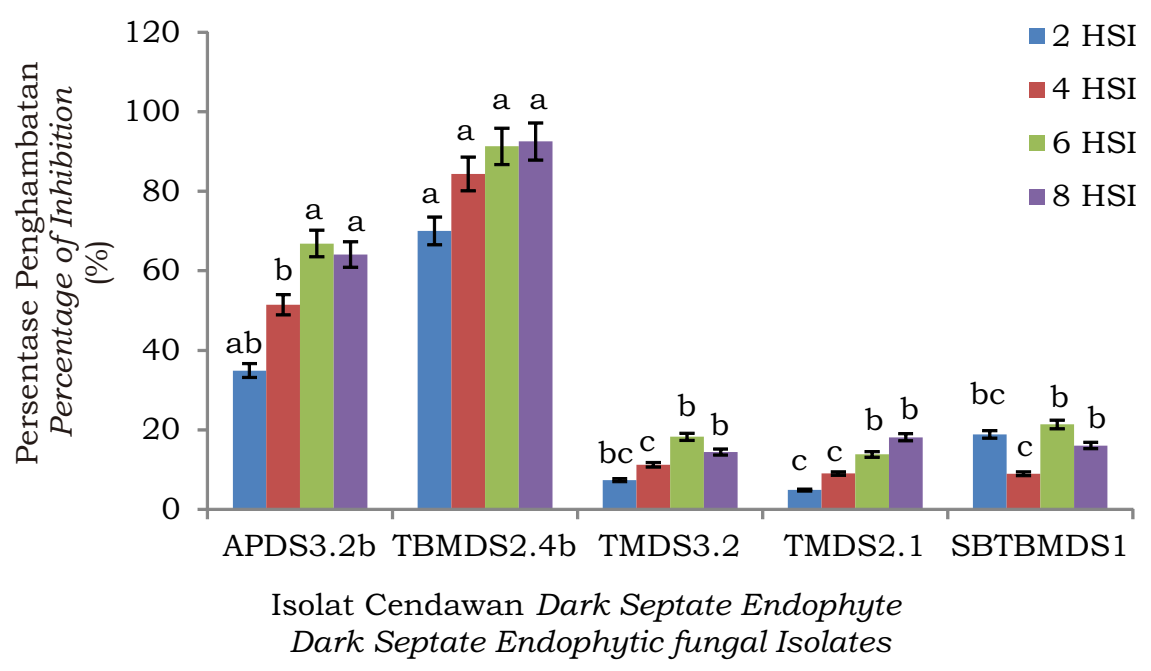

Gambar 3. Persentase penghambatan patogen Rigidoporus microporus karena senyawa volatil organik (VOC) yang dihasilkan oleh isolat cendawan Dark Septate Endophyte pada pengamatan 2, 4, 6, dan 8 hari setelah inokulasi (hsi). Perlakuan yang diikuti oleh huruf yang sama tidak berbeda nyata pada Uji Tukey pada taraf $5 \%$

Figure 3. Percentage of inhibition pathogen Rigidoporus microporus because of volatile organic compounds (VOC) produced by Dark Septate Endophytic fungal isolates at the observation of 2,4, 6 dan 8 days after inoculation (dai). Those with the same letter were not significantly different based on the Tukey Test at 5\% significant level

Mekanisme cendawan endofit dalam melindungi tanaman terhadap serangan patogen dapat terjadi secara langsung dan tidak langsung. Induksi cendawan endofit memacu tanaman dalam pembentukan metabolit sekunder seperti asam salisilat, asam jasmonat, dan etilen yang berfungsi dalam pertahanan tanaman terhadap serangan patogen atau yang berfungsi sebagai antimikroba seperti fitoaleksin (Gao et al., 2010).

\section{KESIMPULAN}

Berdasarkan hasil penelitian ini disimpulkan bahwa cendawan DSE dapat diisolasi dari akar dan tanah sekitar perakaran karet. Hasil seleksi diperoleh lima Cendawan DSE APDS 3.2; TBMDS 2.4b; TMDS 3.2; TMDS 2.1 dan SBTBMDS 1 yang memiliki potensi sebagai agensia hayati penyakit jamur akar putih yang disebabkan oleh Rigidoporus microporus. Isolat APDS 3.2 dan TBMDS 2.4b mampu memproduksi senyawa volatile yang berpotensi sebagai senyawa antimikrob dari cendawan patogen $R$. microporus. Perlu dilakukan pengujian lebih lanjut untuk mengetahui apakah isolat-isolat tersebut juga mampu menekan serangan JAP di lapangan dan memacu pertumbuhan tanaman karet sehingga diharapkan nantinya diperoleh suatu formulasi yang memiliki multifungsi. Identifikasi secara morfologi dan molekuler juga perlu dilakukan setelah diketahui keefektivitasannya di lapangan.

\section{UCAPAN TERIMA KASIH}

Pada kesempatan ini penulis menyampaikan terima kasih karena penelitian ini sebagian didukung oleh penelitian kolaborasi antara Balai Penelitian Tanah dan Pusat Penelitian Karet melalui Program Sinergi PUI, Kementerian Riset, Teknologi, dan Pendidikan Tinggi Nomor SPK $0170 / \mathrm{PPK}-\mathrm{SPK} / \mathrm{III} / 2019$ dan B 81/HK.230/H.8.2/03/2019.

\section{DAFTAR PUSTAKA}

Agrios, G. N. (2005). Plant pathology. Fifth Edition. USA: Elsevier Academic Press.

Amaria, W., Taufiq, E., \& Harni, R. (2013). Seleksi dan identifikasi jamur antagonis sebagai agens hayati jamur akar putih (Rigidoporus microporus) pada tanaman karet. Buletin Ristri, 4 (1), 55-64. Doi : 10.21082/jtidp.v4n1. 2013.p55-64. 
Andrade-Linares, D.R., Grosch, R., Franken, P., Rexer, K.H., Kost, G.W., Restrepo, S., de Garcia, M.C.C., \& Maximova, E. (2011). Colonization of roots of cultivated Solanum lycopersicum by dark septate and other ascomycetous endophytes. Mycologia, 103(4), 710721. Doi : 10.3852/10-329.

Compant, S., Duffy, B., Nowak, J., Clement, C., \& Barka, E.A. (2005). Use of plant growth-promoting bacteria for biocontrol of plant disease: principle, mechanisms of action, and future prospects. Appl Environ Microbiol, 71 (9) , 4951 - 4959. Doi : 10.1128/AEM.71.9.4951-4959.2005.

Fairuzah, Z., Dalimunthe, C.I., Karyudi, Suryaman, S., \& Widhayati, W.E. (2012). Efektivitas Endohevea dalam mengendalikan penyakit jamur akar putih pada tanaman karet. Prosiding Konferensi Nasional Karet (pp. 259268). Yogyakarta, Indonesia : Pusat Penelitian Karet.

Gao, F.K., Dai, C.C., \& Liu, X.Z. (2010). Mechanisms of fungal endophytes in plant protection against pathogens. African Journal of Microbiology Research, 4(13), 1346-1351.

Irawati, A.F.C., Mutaqin, K.H., Sastro, M.T.S.Y., Sulastri., \& Widodo. (2017). Eksplorasi dan pengaruh cendawan endofit yang berasal dari akar tan a m a cabai terhadap pertumbuhan benih cabai merah. Jurnal Hortikultura, 27(1), 105-112. Doi: $10.21082 /$ jhort.v27n1.2017. p105-112

Jayasinghe, C.K. (2010). White root disease of rubber tree: an overview. Proceedings of International Workshop on White root rot disease of Hevea Rubber (8p). Colombo, Sri-Lanka : Rubber Research Institute of Sri Lanka.

Jayasuriya, K.E., \& Thennakoon, B.I. (2007). Biological control of Rigidoporus microporus, the cause of white root disease in rubber. Cey. J. Sci. (Bio. Sci.), 36(1), 9- 16.
Jia, M., Chen, L., Xin, H.L., Zheng, C.J., Rahman, K., Han, T., \& Qin, L.P. (2016). A friendly relationship between endophytic fungi and medicinal plants: A systematic review. Frontiers in Microbiology, 7, $14 \mathrm{p}$. Doi:10.3389/fmicb.2016.00906.

Jumpponen, A., \& Trappe, J.M. (1998). Dark septate endophytes: a review of facultative biotrophic root-colonizing fungi. New Phytologist, 140(2), 295310 . Doi: $10.1046 / \mathrm{j} .1469$ $8137.1998 .00265 x$

Kaewchai, S., \& Soytong, K. (2010). Application of biofungicides against Rigidoporus microporus causing white root disease of rubber trees. Journal of Agricultural Technology, 6(2), 349-363.

Liu, H., Li, T., Ding, Y., Yang, Y., \& Zhao, Z. (2017). Dark septate endophytes colonizing the roots of 'nonmycorrhizal' plants in a mine tailing pond and in a relatively undisturbed environment, Southwest China. Journal of Plant Interactions, 12(1), 264-271. Doi: 10.1080/17429145. 2017.1333635 .

Mahmoud, R.S., \& Narisawa, K. (2013). A $\mathrm{n}$ e w f u n a 1 e ndophy te, Scolecobasidium humicola, promotes tomato growth under organic nitrogen conditions. PLOS ONE, 8(11), e78746. Doi: 10.1371/journal.pone.0078746

Narisawa, K. (2008). Collection of darkseptate endophytic fungi from forest soil at the southwest subtropics in Japan. Ann. Rep. Natl. Inst. Agrobiol. Res., 21, 1-6.

Raza, W., Yuan, J., Ling, N., Huang, Q., \& Shen, Q. (2015). Production of volatile organic compounds by an antagonistic strain Paenibacillus polymyxa WR-2 in the presence of root exudates and organic fertilizer and their antifungal activity against Fusarium oxysporum f. sp. niveum. Biological Control, 80, 89-95. Doi: 10.1016/j.biocontrol .2014 .09 .004 
Rodriguez, R.J., White, Jr.J.F., Arnold, A.E., \& Redman, R.S. (2009). Fungal endophytes: diversity and functional roles. New Phytologist, 182(2), 314330. Doi: 10.1111/j.1469-8137.2009. 02773.x

Santos, S.G.D., Silva, P.R.A.D., Garcia, A.C., Zili, J.E., \& Berbara, J.E. (2016). Dark septate endophyte decreases stress on rice plants. Brazilian J. of Microbiol., 48(2), 333-341. Doi : 10.1016/j.bjm. 2016.09 .018

Setyawan, B., Pawirosoemardjo S., \& Hadi, H. (2013). Trichoderma-based biofungicide "TRIKO COMBI" as a control method against white root disease on hevea rubber. Warta Perkaretan, 32(2), $83-94$.

Sieber, T.N., \& Grünig, C.R. (2006). Biodiversity of fungal root-endophyte communities and populations, in particular of the dark septate endophyte Phialocephala fortinii s.I. Soil Biology. Microbial Root Endophytes, 9, 107-132. Doi: 10.1007 /3-540-33526-9_7.

Siri-udom, S., Suwannarach, N., \& Lumyong, S. (2015). Existence of Muscodor vitigenus, $M$. equiseti and $M$. heveae sp. nov. in leaves of the rubber tree (Hevea brasiliensis Müll.Arg.), and their biocontrol potential. Ann Microbiol, $66,437-448$ Doi: $10.1007 /$ s 13213-015-1126-x.

Situmorang, A., Suryaningtyas, H., \& Pawirosoemardjo, S. (2007). Current status of white root disease (Rigidoporus microporus) and the disease control management in rubber plantation of Indonesia. Proc. International Workshop on White Root Disease of Hevea Rubber (pp. 27-33). Salatiga, Indonesia: IRRI.
Sondergaard, T.E., Sculz, A., \& Palmgren, M.G. (2004). Energization of transport processes in plants. Roles of the plasma membrane $\mathrm{H}^{+}$-ATPase. Plant Physiol., 136, 2475 - 2482. Doi : $10.1104 /$ pp. 104.048231 .

Surono. (2017). The role of dark septate endophytic fungus, Phialocephala fortinii, on promoting Asparagus officinalis growth under various stressed conditions, (Doctoral Thesis), Tokyo University of Agriculture and Technology, Japan.

Surono, \& Narisawa, K. (2017). The dark septate endophytic fungus Phialocephala fortinii is a potential decomposer of soil organic compounds and a promoter of Asparagus officinalis growth. Fungal Ecology, 28, 1-10. Doi: $10.1016 /$ j.funeco.2017.04.001.

Surono, \& Narisawa, K. (2018). The inhibitory role of dark septate endophytic fungus Phialocephala fortinii against Fusarium disease on the Asparagus officinalis growth in organic source conditions. Biological Control, 121, 159-167. Doi: 10.1016/ j.biocontrol.2018.02.017

Waruwu, A., Soekarno, B.P.W., \& Munif, A. (2016). Metabolite of endophytic fungi isolated from rice as an alternative to control seed-borne pathogenic fungi on rice. Jurnal Fitopatologi Indonesia, 12(2), 53-61.

Wheatley, R.E. (2002). The consequences of volatile organic compound mediated bacterial and fungal interactions. Antonie van Leeuwenhoek., 81, 357 364. 